\title{
Effects and mechanism of juglone in combination with 5-FU on colon cancer CT-26 cells in vivo
}

\author{
Tianyu Liu, Yan $\mathrm{Li}^{\mathrm{a}}$ and $\mathrm{Na} \mathrm{Li}$ \\ School of Life Science, 100081 Beijing Institute of Technology, China
}

\begin{abstract}
The effects and mechanism of juglone alone or combined with 5-fluorouracil on colon cancer CT-26 cells were examined in vivo. Starting at 5 weeks of age, male Balb/c mice were transplanted the CT-26 cells and treated with juglone alone or combined with 5fluorouracil. Observed the morphologic characteristics of tumor tissue by HE staining after treatment of 9 days. We detected the content of IL-2, VEGF and IFN- $\gamma$ in serum and the protein expression of ki-67, E-cad and Bcl-2 in tumor tissue. The inhibition rate of animals given low-dose or high-dose juglone alone and combined with 5 -fluorouracil is $31.73 \%, 40.38 \%$, $56.73 \%$ and $75.01 \%$ respectively. Animals given juglone alone or combined with 5 -fluorouracil could increase the content of IL-2 and IFN- $\gamma$ in serum and the expression of E-cad and decrease the content of VEGF in serum and the expression of ki-67 and Bcl-2 significantly compared with those injected $2 \%$ ethanol NS $(P<0.05$ in each). The present data suggest that the juglone could reduce the risk of CT-26 cells metastasis and proliferation and enhance the function of the immune system. The possible anti-tumor mechanism of juglone is down-regulated expression of $\mathrm{Bcl}-2$ to induce the apoptosis of tumor cells.
\end{abstract}

\section{Introduction}

Colon cancer as one of the malignant digestive tumor is a major global health problem[1]. Using extensively surgical remove, combined with chemotherapy and radiotherapy after operation is effective in treating colon cancer currently. 5 - fluorouracil, a metabolic type of antitumor drugs, is recognized in clinical to treat colon cancer and other digestive tract cancer [2]. Because of the significant effect on the treatment of colon cancer, 5 - fluorouracil has been applied widely as the first-line drug of colorectal carcinoma chemotherapy. Recent evidence has shown that patients have developed a resistance which potentially has decreased the proportion of people who could be cured [3]. The other main side effects of 5 - fluorouracil are myelosuppression and hemorrhagic enteritis and its low lipophilicity, bad selectivity and evident side effects also limit its application. Juglone (5-hydroxy-1,4-naphthoquinone), a hydroxy naphthoquinone compound, is derived from the fresh root bark, branch bark or green peel of Juglansmandshurica [4]. Many data derived from laboratory studies have suggested that juglone has a good antitumor activity both in vitro or vivo. It has obvious inhibitory effect on the proliferation of Hela cells and esophageal cancer cells in vitro and breast cancer cells, stomach cancer cells and S180 solid cells in mice [5-8]. However, there is no report

${ }^{a}$ Corresponding author: 2120151319@bit.edu.cn

(C) The Authors, published by EDP Sciences. This is an open access article distributed under the terms of the Creative Commons Attribution License 4.0 (http://creativecommons.org/licenses/by/4.0/). 
about the effect of juglone on colon cancer in vivo. In this study, the effects and mechanism of juglone alone or combined with 5-fluorouracil on colon cancer CT-26 cells were examined in vivo. In addition, the effects of juglone and juglone combined with 5-fluorouracil on immune function in vivo is discussed.

\section{Materials and methods}

\subsection{Animals, cells, test drugs and chemical reagents}

60 male Balb/c mice, which were purchased from Peking University Health Science Center (Beijing, China), were used. CT-26 cells were purchased from Peking Union Medical College (Beijing, China). Juglone was purchased from Sigma. 5-fluorouracil was purchased from Beijing Coal General Hospital (Beijing, China).

All animals were housed in plastic cages (ten mouse per cage). They had free access to water and diets under controlled environmental conditions of humidity $(50 \pm 10 \%)$, lighting $(12 \mathrm{~h}$ light/dark cycle) and temperature $\left(23 \pm 2^{\circ} \mathrm{C}\right)$. CT-26 cells of a suitable concentration were inoculated in culture flasks containing RPMI-1640 solution with $10 \%$ of fetal bovine serum. The cultures were then incubated at $37^{\circ} \mathrm{C}$, with $5 \% \mathrm{CO}_{2}$ and saturated humidity; culture transfer was performed once every 2-3 days. The test drugs and chemical reagents were stored in the freezer $\left(4^{\circ} \mathrm{C}\right)$.

\subsection{Experimental procedure}

The study was performed after the mice were allowed to acclimate for 5 days. CT-26 colon cancer mouse models were made on the sixth day by transplanting $0.2 \mathrm{~mL} \mathrm{CT}-26$ cell suspension $\left(1 \times 10^{7} / \mathrm{mL}\right)$ in the mouse left anterior subcutaneous part. Juglone and 5-fluorouracil were injection via abdominal according to the following group once a day. A total of 60 mice of 5 weeks of age were divided into six groups as follows: group 1, 10 mice for $2 \%$ ethanol NS as model group; group 2, 10 mice for 5 -fluorouracil (20mg/kg 5-FU) alone as positive drug group; group 3, 10 mice for high-dose juglone $(5 \mathrm{mg} / \mathrm{kg})$ alone; group 4,10 mice for low-dose juglone $(2.5 \mathrm{mg} / \mathrm{kg})$ alone; group 5,10 mice for juglone $(5 \mathrm{mg} / \mathrm{kg})$ combined with 5 -fluorouracil $(20 \mathrm{mg} / \mathrm{kg} 5$-FU); group 6,10 mice for juglone $(5 \mathrm{mg} / \mathrm{kg})$ combined with 5-fluorouracil (10mg/kg 5-FU). After 9 days, complete autopsies were performed on all animals after weighed and took blood by removalling eyeball. At autopsy, the size (length, width and height) of tumors were measured and the maximum size was selected for analysis. Thymus and spleen were examined cautiously. Tumor tissues were fixed in $10 \%$ buffered formalin, embedded in paraffin blocks and processed by routine histological methods with hematoxylin and eosin stains, then Calculated the expression rate of nuclear factor Ki-67, E- cadherin (E-cad), B-cell lymphoma 2 gene (Bcl-2). Calculated tumor inhibition rate, thymus and spleen indexes and determined the content of interleukin -2 (IL-2), interferon- $\gamma$ (IFN- $\gamma$ ), vascular endothelial growth factor (VEGF) by Elisa.

\subsection{Statistical analysis}

Statistical evaluation was done using the SPSS 17.0 and ANOVA. Results presented as mean \pm standard deviation $(\overline{\mathrm{x}} \pm \mathrm{SD})$. 


\section{Results}

\subsection{Effect of juglone and juglone combined with 5-fluorouracil on proliferation of CT-26 in mice}

Table 1 indicates that The inhibition rate of animals given low-dose or high-dose juglone alone and combined with low-dose or high-dose 5 -fluorouracil is $31.73 \%, 40.38 \%, 56.73 \%$ and $75.01 \%$ respectively. These data showed that juglone combined with 5 -fluorouracil was more cytotoxic than juglone alone and the effect of juglone combined with 5 -fluorouracil $(20 \mathrm{mg} / \mathrm{kg} 5$-FU) was better than 5 -fluorouracil $(20 \mathrm{mg} / \mathrm{kg} \mathrm{5-FU)}$, indicating that juglone may have a good anti-cancer effect on CT-26 cells. The expression rate of nuclear factor ki-67 is closely related to the cell proliferation. Compared with the model group, the expression rate of ki-67 were significantly decreased when animals were treated with juglone or 5-fluorouracil $(p<0.05)$. Juglone combined with 5 -fluorouracil $(20 \mathrm{mg} / \mathrm{kg} 5$-FU) could better inhibit the expression of ki-67 than 5 -fluorouracil $(20 \mathrm{mg} / \mathrm{kg} 5$-FU) $(p<0.01)$. By observing the morphological characteristics of CT-26 cells (Figure 1), we found both juglone and 5 -fluorouracil could make tumor necrose obviously, such as some nucleus becoming smaller or cells becoming shrinkage even cytolysis. These results are consistent with the experiment of anti-tumor rate.

Table 1 Effect of juglone and 5-fluorouracil on the tumor proliferation in mice $(\overline{\mathrm{x}} \pm \mathrm{SD}, \mathrm{n}=10)$

\begin{tabular}{|c|c|c|c|c|c|}
\hline Group & $\begin{array}{c}\text { Dose of juglone } \\
(\mathrm{mg} / \mathrm{kg})\end{array}$ & $\begin{array}{c}\text { Dose of } \\
\text { 5-FU(mg/kg) }\end{array}$ & Tumor weight $(\mathrm{g})$ & $\begin{array}{c}\text { anti-tumor } \\
\text { rate }(\%)\end{array}$ & $\begin{array}{c}\text { expression rate of } \\
\text { Ki-67(\%) }\end{array}$ \\
\hline Model & - & - & $1.04 \pm 0.21$ & - & $83.28 \pm 10.40$ \\
\hline $5-F U$ & - & 20 & $0.32 \pm 0.19^{\mathrm{b}}$ & $69.23^{\mathrm{b}}$ & $42.85 \pm 11.07^{\mathrm{b}}$ \\
\hline \multirow{2}{*}{ Juglone } & 2.5 & - & $0.71 \pm 0.19^{\mathrm{a}, \mathrm{d}}$ & $31.73^{\mathrm{a}, \mathrm{d}}$ & $66.23 \pm 12.39^{\mathrm{a}}$ \\
\cline { 2 - 6 } & 5 & - & $0.62 \pm 0.17^{\mathrm{b}, \mathrm{c}}$ & $40.38^{\mathrm{b}, \mathrm{c}}$ & $59.67 \pm 6.16^{\mathrm{b}}$ \\
\hline $\begin{array}{c}\text { Juglone } \\
\text { combined with } \\
\text { 5-FU }\end{array}$ & 5 & 10 & $0.45 \pm 0.18^{\mathrm{b}}$ & $56.73^{\mathrm{b}}$ & $43.20 \pm 7.76^{\mathrm{b}}$ \\
\cline { 2 - 6 } & 5 & 20 & $0.26 \pm 0.20^{\mathrm{b}}$ & $75.01^{\mathrm{b}}$ & $20.84 \pm 9.72^{\mathrm{b}, \mathrm{d}}$ \\
\hline
\end{tabular}

${ }^{\mathrm{a}, \mathrm{b}}$ Significantly different from the model group $\left({ }^{\mathrm{a}} P<0.05,{ }^{\mathrm{b}} P<0.01\right)$

${ }^{\mathrm{c}, \mathrm{d}}$ Significantly different from the 5 -FU group ( $\left.{ }^{\mathrm{c}} P<0.05,{ }^{\mathrm{d}} P<0.01\right)$
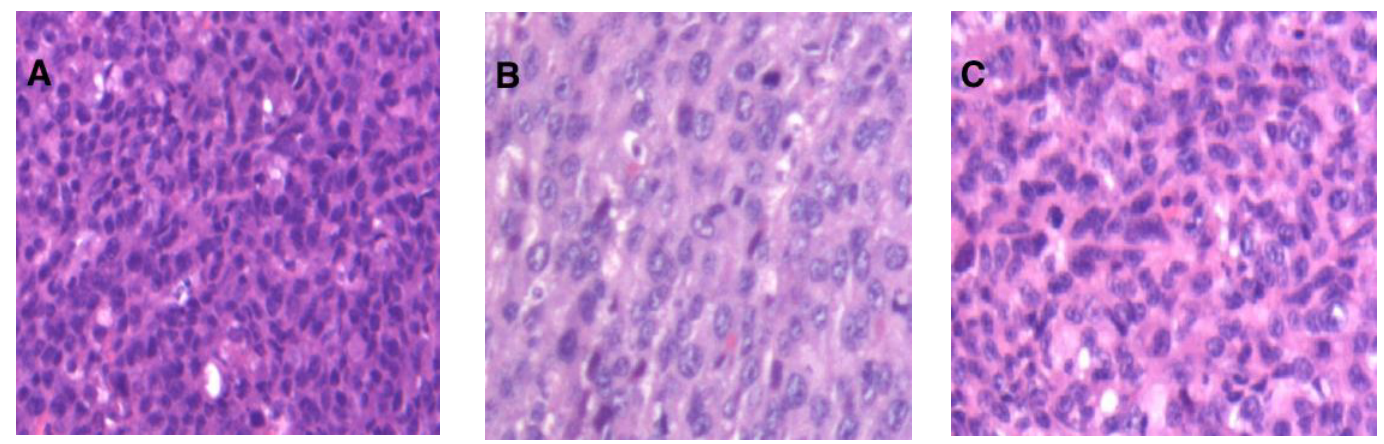

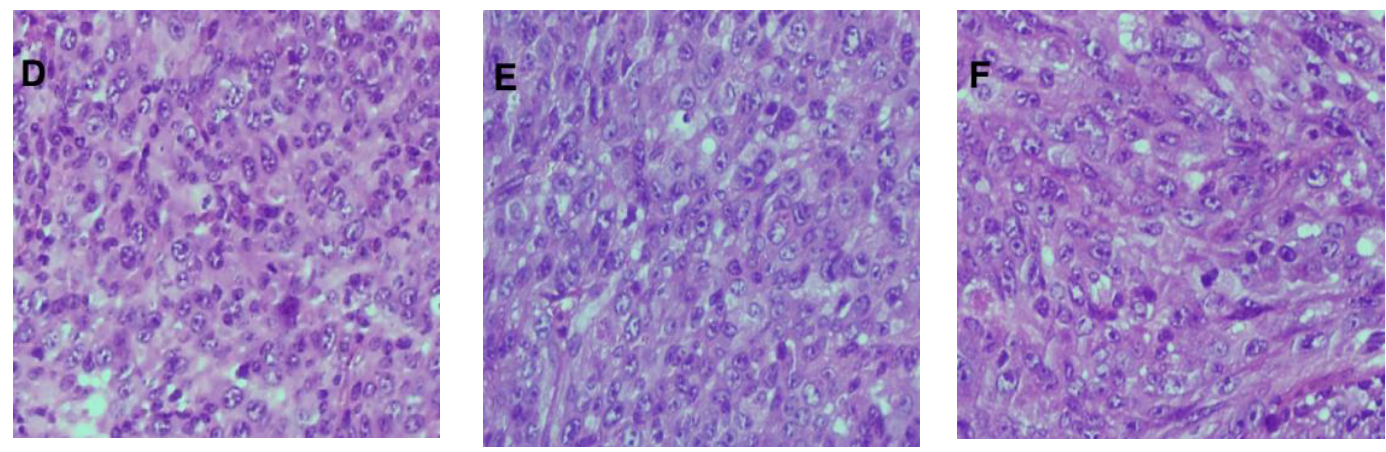

Figure 1. Colon tumour tissues stained with hematoxylin and eosin. A: model ; B: $20 \mathrm{mg} / \mathrm{kg}$ 5-FU; C: $2.5 \mathrm{mg} / \mathrm{kg}$ juglone; D: $5 \mathrm{mg} / \mathrm{kg}$ juglone; E: $5 \mathrm{mg} / \mathrm{kg}$ juglone with $10 \mathrm{mg} / \mathrm{kg} 5-\mathrm{FU}$. F: $5 \mathrm{mg} / \mathrm{kg}$ juglone with $20 \mathrm{mg} / \mathrm{kg} 5-\mathrm{FU}$.

\subsection{Effect of juglone and juglone combined with 5-fluorouracil on metastasis of CT-26 in mice}

VEGF as the main regulator induces tumor angiogenesis and the protein expression of E-cadherin may suggest a cell adhesion. Compared with the model group, the mouse serum VEGF levels of the groups treated with juglone or juglone combined with 5 -fluorouracil is significantly decreased $(P<0.05)$ and similar with the control group which treated with 5-fluorouracil alone. The protein expression of E-cadherin of the groups treated with juglone or juglone combined with 5-fluorouracil is significantly increased $(P<0.01)$ (Table 2$)$. These results suggest that juglone could inhibit proliferation, invasion and metastasis of the tumor in mice.

Table 2 Effect of juglone and 5-fluorouracil on the tumor metastasis in mice $(\overline{\mathrm{x}} \pm \mathrm{SD}, \mathrm{n}=10)$

\begin{tabular}{|c|c|c|c|c|}
\hline Group & $\begin{array}{c}\text { Dose of juglone } \\
(\mathrm{mg} / \mathrm{kg})\end{array}$ & $\begin{array}{c}\text { Dose of } \\
5-\mathrm{FU}(\mathrm{mg} / \mathrm{kg})\end{array}$ & $\begin{array}{c}\text { VEGF } \\
(\mathrm{pg} / \mathrm{mL})\end{array}$ & $\begin{array}{c}\text { E-cad integrated optical } \\
\text { density(IOD })\end{array}$ \\
\hline Model & - & - & $745.42 \pm 18.07$ & $37868 \pm 5234$ \\
\hline \multirow{2}{*}{ 5-FU } & - & 20 & $693.77 \pm 25.94^{\mathrm{b}}$ & $93436 \pm 10646^{\mathrm{b}}$ \\
\hline \multirow{2}{*}{ Juglone } & 2.5 & - & $704.67 \pm 15.47^{\mathrm{a}}$ & $90419 \pm 21256^{\mathrm{b}}$ \\
\cline { 2 - 5 } & 5 & - & $697.80 \pm 15.94^{\mathrm{b}}$ & $88934 \pm 8396^{\mathrm{b}}$ \\
\hline \multirow{2}{*}{$\begin{array}{c}\text { Juglone combined } \\
\text { with 5-FU }\end{array}$} & 5 & 10 & $704.57 \pm 17.88^{\mathrm{b}}$ & $92139 \pm 8025^{\mathrm{b}}$ \\
\cline { 2 - 5 } & 5 & 20 & $681.80 \pm 17.95^{\mathrm{b}}$ & $92777 \pm 15937^{\mathrm{b}}$ \\
\hline
\end{tabular}

${ }^{\mathrm{a}, \mathrm{b}}$ Significantly different from the model group $\left({ }^{\mathrm{a}} P<0.05,{ }^{\mathrm{b}} P<0.01\right)$

\subsection{Effect of juglone and juglone combined with 5-fluorouracil on apoptosis of CT-26 in mice}

Table 3 shows that expression rate of Bcl-2 of the groups treated with juglone or juglone combined with 5-fluorouracil is significantly decreased $(P<0.01)$. It indicates that juglone could down-regulate the expression of Bcl-2 in CT-26 cells to promote apoptosis. 
Table 3 Effect of juglone and 5-fluorouracil on the tumor apoptosis in mice $(\overline{\mathrm{X}} \pm \mathrm{SD}, \mathrm{n}=10)$

\begin{tabular}{|c|c|c|c|}
\hline Group & Dose of juglone $(\mathrm{mg} / \mathrm{kg})$ & Dose of 5-FU $(\mathrm{mg} / \mathrm{kg})$ & expression rate of Bcl-2(\%) \\
\hline Model & - & - & $73.02 \pm 4.87$ \\
\hline 5-FU & - & 20 & $40.29 \pm 6.18^{\mathrm{a}}$ \\
\hline \multirow{2}{*}{ Juglone } & 2.5 & - & $55.71 \pm 5.31^{\mathrm{a}}$ \\
\cline { 2 - 4 } & 5 & - & $51.29 \pm 4.72^{\mathrm{a}}$ \\
\hline \multirow{2}{*}{$\begin{array}{c}\text { Juglone combined with } \\
5-F U\end{array}$} & 5 & 10 & $44.29 \pm 4.43^{\mathrm{a}}$ \\
\cline { 2 - 4 } & 5 & 20 & $38.04 \pm 4.79^{\mathrm{a}}$ \\
\hline
\end{tabular}

${ }^{\mathrm{a}, \mathrm{b}}$ Significantly different from the model group $\left.{ }^{(\mathrm{a}} P<0.01\right)$

\subsection{Effect of juglone and juglone combined with 5-fluorouracil on immunity of mice}

Table 4 shows that thymus index of the groups treated with juglone are significantly increased comparing with the model group and control group $(P<0.01)$. Comparing with the control group, thymus index of the groups treated with juglone combined with 5-fluorouracil are also increased $(P<0.01)$. Juglone and juglone combined with 5 -fluorouracil could also increase the spleen index. The mice serum IL-2 and IFN- $\gamma$ level could be raised after using juglone or juglone combined with 5-fluorouracil.

Table 4 Effect of juglone and 5-fluorouracil on immunity of mice $(\overline{\mathrm{x}} \pm \mathrm{SD}, \mathrm{n}=10)$

\begin{tabular}{|c|c|c|c|c|c|c|}
\hline Group & $\begin{array}{c}\text { Dose of } \\
\text { juglone } \\
(\mathrm{mg} / \mathrm{kg})\end{array}$ & $\begin{array}{c}\text { Dose of } \\
\text { 5-FU(mg/kg) }\end{array}$ & $\begin{array}{c}\text { Thymus } \\
\text { index(mg/g) }\end{array}$ & $\begin{array}{c}\text { Spleen } \\
\text { index(mg/g) }\end{array}$ & $\begin{array}{c}\text { IL-2 } \\
(\mathrm{pg} / \mathrm{mL})\end{array}$ & $\begin{array}{c}\text { IFN- } \gamma \\
(\mathrm{pg} / \mathrm{mL})\end{array}$ \\
\hline Model & - & - & $2.42 \pm 0.71$ & $4.15 \pm 1.04$ & $112.92 \pm 7.32$ & $285.83 \pm 22.95$ \\
\hline $5-F U$ & - & 20 & $0.64 \pm 0.15^{\mathrm{b}}$ & $3.72 \pm 0.61$ & $131.34 \pm 5.77^{\mathrm{b}}$ & $328.57 \pm 17.85^{\mathrm{a}}$ \\
\hline \multirow{2}{*}{ Juglone } & 2.5 & - & $3.47 \pm 0.58^{\mathrm{b}, \mathrm{d}}$ & $4.29 \pm 0.37$ & $132.29 \pm 6.27^{\mathrm{b}}$ & $331.43 \pm 16.38^{\mathrm{b}}$ \\
\cline { 2 - 7 } & 5 & - & $3.64 \pm 0.38^{\mathrm{b}, \mathrm{d}}$ & $6.81 \pm 1.13^{\mathrm{b}, \mathrm{d}}$ & $131.25 \pm 5.78^{\mathrm{b}}$ & $332.92 \pm 17.64^{\mathrm{b}}$ \\
\hline $\begin{array}{c}\text { Juglone } \\
\text { combined } \\
\text { with 5-FU }\end{array}$ & 5 & 10 & $2.10 \pm 0.76^{\mathrm{d}}$ & $6.19 \pm 1.34^{\mathrm{b}, \mathrm{d}}$ & $138.23 \pm 7.43^{\mathrm{b}}$ & $342.14 \pm 29.63^{\mathrm{b}}$ \\
\cline { 2 - 7 } & 5 & 20 & $2.01 \pm 0.43^{\mathrm{d}}$ & $6.31 \pm 1.54^{\mathrm{b}, \mathrm{d}}$ & $134.69 \pm 6.32^{\mathrm{b}}$ & $362.92 \pm 20.76^{\mathrm{b}, \mathrm{c}}$ \\
\hline
\end{tabular}

a, b Significantly different from the model group $\left({ }^{\mathrm{a}} P<0.05,{ }^{\mathrm{b}} P<0.01\right)$

c, d Significantly different from the 5-FU group $\left({ }^{\mathrm{c}} P<0.05,{ }^{\mathrm{d}} P<0.01\right)$

\section{Discussion}

In this study, juglone could inhibit the tumor proliferation in mice obviously. Juglone could reduce the risk of proliferation and metastasis of tumor cells by decreasing the level of VEGF in serum and increasing the protein expression of E-cadherin. Furthermore, juglone may improve immune function by increasing some immune factors such as IL-2, INF- $\gamma$ to improve antitumor activities. The effect of juglone combined with 5-fluorouracil on antitumor is enhanced apparently. And this measure could reduce the side effects of 5-fluorouracil like impaired immune function. The antitumor mechanism of juglone may be involved in blocking Bcl-2 protein expression to induce tumor cells apoptosis. In conclusion, juglone may be a new promising chemotherapeutics for colon cancer. 


\section{References}

1. M. R. Buunen, W. Hop, et al. "Survival after laparoscopic surgery versus open surgery for colon cancer: long-term outcome of a randomised clinical trial." Lancet Oncology 10.1(2009):44-52.

2. J. Li, et al. "Inhibition of autophagy augments 5-fluorouracil chemotherapy in human colon cancer in vitro and in vivo model." European Journal of Cancer 46.10(2010):1900-1909.

3. R. L. Zhai, X. M. Zhang, et al. "Relationship between O 6 -methylguanine-DNA methytransferase expression in colon cancer stem cells and acquired 5-Fu chemotherapy drug resistance in colon cancer cells." Chinese Journal of Experimental Surgery 31 (2014):248-250.

4. A. Ohta, P.M. Sivalingam, et al. "Isolation of naphthazarin from walnut 'Onigurumi', and its inhibitory action on oxidative phosphorylation in mitochondria." Toxicon 11.3(1973):235-241.

5. W. Zhang, X. Y. Zhao, et al. "Effects of different concentrations of juglone on the proliferation and apoptosis of HeLa cells." Medical Journal of Chinese Peoples Liberation Army 38.2(2013).

6. L. Li, P. Chen, et al. "Juglone inhibits the proliferation of human esophageal carcinoma EC1 cells." World Chinese Journal of Digestology 18.11(2010):1147-1151.

7. M. T. Paulsen, M. Ljungman. "The natural toxin juglone causes degradation of p53 and induces rapid H2AX phosphorylation and cell death in human fibroblasts."Toxicology \& Applied Pharmacology 209.1(2005):1-9.

8. Y. B. Ji, et al. "Studies on Inhibition of Juglone in Exocarpium Juglandis Immaturum on S(180) Sarcoma in Mice." Journal of Chinese Pharmaceutical Sciences 44.3(2009):195-199. 